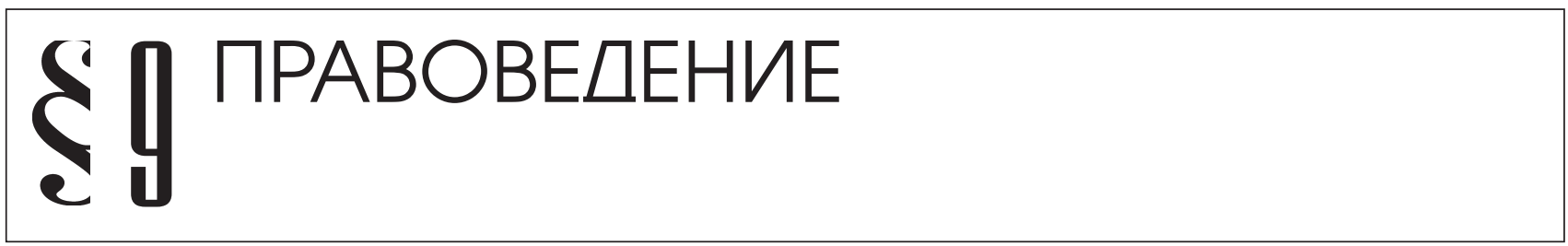

\title{
НОВАЯ ПАРАДИГМА ГРАЖДАНСКО-ПРАВОВЫХ ПОСТУПКОВ: ТЕОРЕТИКО-ЭМПИРИЧЕСКИЕ АСПЕКТЫ
}

\begin{abstract}
Аннотация: переход России на инновационный путь развития предполагает необходимость активизации деятельности участников общественных отношений и поиска средств стимулирования их инициативных действий-поступков, направленных на достижение эффективности и устойчивости общественного производства. В настоящей статье представлена новая парадигма гражданско-правовых поступков и показано их место в правовом регулировании социиально-экономических отношений.
\end{abstract}

Ключевые слова: юриспруденция, гражданский, факт, поступки, юридический, экономика, человек, потенциил, отношение, регулирование.

\section{1. Предпосылки проблемы.}

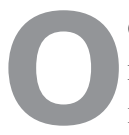
сновными целями социально-экономического развития страны являются формирование цивилизованного гражданского общества, где в полной мере будут обеспечены права человека, гражданские и политические свободы, а также превращение её в государство с модернизированной и конкурентоспособной рыночной экономикой посредством реализации ряда национальных проектов, в частности в области модернизации и технологического обновления всей производственной сферы, образования, здравоохранения, жилищного строительства и сельского хозяйства ${ }^{1}$. Достижение высоких темпов хозяйственного роста, удвоение валового внутреннего продукта в ближайшее десятилетие и обеспечение должного уровня экономической свободы, готовности предпринимателей вкладывать деньги в бизнес объявлены в качестве первостепенных задач экономики страны и её субъектов.

Решение поставленных задач видится на путях создания равных условий конкуренции, упрочения собственности, осуществления конкретных шагов по изменению структуры экономики, придания ему инновационного качества, привлечения инвестиций и правильного и обоснованного выбора направлений их использования,

\footnotetext{
${ }^{1}$ Послания Президента России Владимира Путина Федеральному Собранию РФ: 2006 год. / Российская газета. 2006. 11 мая (4063) и 2009 год. / Российская газета. 2009. 19 ноября (№5038); Концепция долгосрочного социально-экономического развития Российской Федерации на период до 2020 года, утв. Правительством Российской Федерации распоряжением от 17 ноября 2009 года №1121-р / СЗ РФ. 2008. №47. Ст. 5489.
}

стимулирования всех видов, в первую очередь, научнотехнического и технологического творчества, внедрения результатов последнего на базе научно-реализационной инфраструктуры (технико-внедренческие зоны, технопарки, целевое прогнозирование и программирование, пилотное проектирование, индикативное планирование, венчурные и инвестиционные фонды и т.п.), т.е. в совершении субъектами гражданского оборота фактических действий, нацеленных на социально-экономические и иные общеполезные результаты. Претворение в жизнь этих целей и задач неразрывно связано не только с расширением в общественно политической деятельности и хозяйствовании инициативных начал, свободы мышления, усмотрения в обосновании организационных усилий, использовании имущества, материальной базы производства, но и правовым обеспечением и регулированием разработанных и принятых к исполнению мероприятий, их юридическим признанием. Право призвано в законодательной форме закреплять обусловленные современной социально-экономической ситуацией общественно производственные отношения, тем самым оказывая должное воздействие на них в достижении оптимальной жизнедеятельности физических и юридических лиц.

Как показала деятельность по гражданско-правовому регулированию общественных отношений, многие концептуальные положения, нашедшие своё отражение в настоящей работе, оказались научно обоснованными и достоверными. Главный вывод о необходимости существенного расширения круга юридических фактов, как действенных элементов механизма гражданско-правового регламентирования общественных связей, за счёт вновь обнаруженных (нормативные условия, отдельные 


\section{Право и политика $1(157) \cdot 2013$}

разновидности бездействий, общественные события) или признанных хозяйственной, административной и судебной практикой (иные действия) и выдержавших испытание временем, нашел своё признание. Более того, он открыл путь к более масштабному использованию в правотворческой и правоприменительной работе государственных органов ранее малоисследованных, но способных инициировать поистине колоссальные материальные поступления и продиктованных нуждами социально-экономического развития страны фактических обстоятельств типа действий, совершаемых усмотрением участников общественных отношений.

В условиях юридической регламентации последних в стране и государстве важное значение приобретает дальнейшее изучение фактических и правовых оснований возникновения и движения социальных, экономических и других связей. В первую очередь тех из них, которые, как нам представляются, занимают доминантное положение в организации и осуществлении любого вида общественной и гражданской (имущественной, хозяйственной, интеллектуальной) деятельности и которые, поэтому, в большинстве своём выступают легальными титулами гражданских правоотношений, то есть гражданско-правовыми поступками.

\section{2. Юридические поступки: понятие, содержание, правовые основы.}

Гражданское право, как и общая теория права, во все периоды своего развития, особенно в советский период, уделяло большое внимание проблеме правоотношения, его понятийным элементам (сущности, содержанию, субъектам, механизму воздействия на имущественно-стоимостные и отдельные личные неимущественные отношения) $)^{2}$.

Важное место отводилось учению об основаниях его возникновения и движения. К сожалению, в годы проводимых в стране реформ научное обсуждение

\footnotetext{
${ }^{2}$ Иоффе O.C. Правоотношение по советскому гражданскому праву. - М.: 1949; Новиикий И.Б., Лунц Л.А. Общее учение об обязательстве. - М.: 1950; Новиикий И.Б. Сделки. Исковая давность. - М.: 1954; Александров Н.Г. Законность и правоотношения в советском обществе. - М.: 1955; Красавчиков О.А. Юридические факты в советском гражданском праве. - М.: 1958; Толстой Ю.К. К теории правоотношения. - Л.: 1959; Алексеев С.С. Общая теория социалистического права. В 4-х вып. - Свердловск.: 1963-1966; Матвеев Г.К. Основания гражданско-правовой ответственности. - М.: 1970; Врублевский Е. Бездействие и причинность / Правоведение. 1971. №1; Ханнанов Р.А. Правовая природа бездействия и каузальность / Советское государство и право. 1978. №4; Алексеев С.С. Общая теория права. В 2-х томах. - М.: 1981, 1982; его же. Теория права. 2-е изд., перераб. и доп. - М.: Бек, 1995; Бабаев В.К. Социалистические правовые отношения. - Владивосток.: 1992; Рябов А.E. Юридические факты в механизме правового регулирования. Дисс. канд. юрид. наук. - Н. Новгород.: 2001. и др.
}

затронутой проблемы стало отходить на второй план из-за неправильного сочетания теоретического и практического в науке, угасания интереса к теории как основе успешной законотворческой деятельности, нигилистического отношения государства к фундаментальным научным исследованиям, увлечения прикладной стороной научных разработок, ожидания от них быстрого практического результата.

Однако изменение социалистических основ жизни общества и, в первую очередь, претворение в жизнь принципов правового государства и обеспечение социальных и иных свобод и прав человека и гражданина, переход к рыночным формам хозяйствования требуют немедленной стабилизации и роста эффективности общественного производства и, как следствие этого, упреждения многочисленных фактов отмены нормативных актов, регулирующих гражданские (хозяйственные) отношения и закрепляющих их устойчивость, внесения в них бесконечных поправок, изменений и дополнений, утверждения действенного гражданско-правового регулирования в сфере экономики и социального бытия на базе основополагающих норм ст. 1 Гражданского кодекса Российской Федерации.

В изложенном контексте проблема охватывает область теории юридических фактов в целом, а в рамках последней - сферу испытывающего на себе тенденцию постепенного забвения учения об отдельных видах юридических фактов, а также обстоятельствах, тесно с ними связанных, в частности, развитые наукой гражданского права положения об общественных событиях ${ }^{3}$, о бездействии и классификации его разновидностей и правовой значимости ${ }^{4}$, о нормативных условиях ${ }^{5}$, признанные научной общественностью России $^{6}$ и стран зарубежья ${ }^{7}$, слабо внедряется в правотворческую и правоприменительную практику.

\footnotetext{
${ }^{3}$ Ханнанов Р.А. Правовое регулирование сельскохозяйственного производства. - Уфа.: 1976; его же. Юридические события в динамике гражданского оборота. - Уфа.: Деп. в ИНИОН АН СССР 14.02.85 №19612, 1985.

${ }^{4}$ Ханнанов Р.А. Правовая природа бездействия и каузальность / Советское государство и право. 1978. №4. С. 124-128.

${ }^{5}$ Ханнанов P.A. Нормативные условия в динамике гражданского правоотношения / Советское государство и право. 1973. №8.

${ }^{6}$ Алексеев С.С. Общая теория права. - М.: 1982; Данилин В.И., Реутов С.И. Юридические факты в советском семейном праве. - Свердловск.: 1989; Ханнанова Т.Р., Аминева А.Д. Проблемы аграрно-правового регулирования финансовой деятельности сельскохозяйственных коммерческих организаций в условиях рынка. - М.: 2004; Воронин Б.А. Аграрно-правовая наука России/ Аграрное и земельное право. 2005. №1 и др.

${ }^{7}$ Hannanov R.A. EVENIMENTELE IN DINAMICA RAPORTURILOR JURIDICE SOCIALISTE. / STUDII SI CERCETARI JURIDICE. 1977. №1 (AH CPC); HANNANOV R.A. A nemtevës jogi fermëszete ës az oksagi kapcsolat / JOGTUDOMANYI KÖZLONY. 1978. №8 (AH BHP).
} 
Подход к некоторым видам юридических фактов, прежде всего, к юридическим поступкам, как к категориям раз и навсегда данным и бесспорным постулатам, как к бессодержательным законодательным обстоятельствам, мешает разрешению проблемы (ст. ст. 8, 227, 230, 233 ГК РФ и др.). Нормы гражданского права, посвященные конкретным разновидностям таких поступков (находка, безнадзорные скот и животные, клад) вследствие их незначительного распространения далеки от реальной действительности и не могут оказать ощутимого позитивного влияния на состояние отношений гражданского оборота. Отсутствует научно обоснованное и легальное определение понятий иных действий граждан и юридических лиц (абз. 8 п. 1 ст. 8 ГК РФ), а также юридических поступков как разновидности подобных актов.

Существование более широкого круга юридических поступков было отмечено М.М. Агарковым. «Теория юридических фактов знает целый ряд действий», - писал он, - «которые не являются ни сделками, ни правонарушениями, тем не менее, порождают, изменяют и прекращают правоотношения» ${ }^{8}$. К числу таких фактов он относил «дозволенные действия, которые не являются волеизъявлениями, направленными на юридические последствия (признание фактов, уведомление о фактах прошлых, настоящих и будущих), но влекущие правовые последствия независимо от направленности их на эти последствия»?.

Указанный М.М. Агарковым круг юридических поступков не ограничивается приведенными выше фактами, на что правильно обратил внимание О.А. Красавчиков. По его мнению, к поступкам, имеющим правовое значение, должны быть отнесены «...ещё явления и несколько отличные от перечисленных, но с юридической точки зрения сходные с ними»: исполнение обязанности, создание нового материального и духовного блага, выбор кредитором предмета исполнения по альтернативному обязательству, досрочный возврат предмета займа должником, действия лица по защите охраняемых законом прав и интересов от посягательств третьих лиц или акты по защите материальных благ от опасности уничтожения их в результате проявления отрицательных сил природы ${ }^{10}$.

Таким образом, и О.А. Красавчиков под юридическими поступками понимал правомерные действия, с которыми нормы права связывают юридические последствия независимо от направленности этих действий на указанные последствия. Так известно, что все юридические факты гражданского права по волевому признаку подразделяются на события и действия. Обстоятельства,

\footnotetext{
${ }^{8}$ Агарков М.М. Учение о ценных бумагах. - М.: 1927. С. 95.

${ }^{9}$ Агарков М.M. Понятие сделки по советскому гражданскому праву / Советское государство и право. 1946. № 3-4. С. 51-52.

${ }^{10}$ Красавчиков О.А. Юридические факты в советском гражданском праве. - М.: 1958. С. 154.
}

относимые к разряду юридических поступков, ни при каких условиях не могут быть причислены к группе событий. События - это явления, происходящие независимо от воли людей ${ }^{11}$ и протекающие помимо воли человека. Юридические поступки всегда представляют собой волеизъявления, сознательные акты человеческого бытия. Самого сущностного различия интересующих нас фактов вполне достаточно для отграничения их от событий.

Но истинно и то, что юридические поступки - это акты человеческого поведения. Поэтому практически и теоретически очень важно установить их отличие от однопорядковых и им подобных обстоятельств, т.е. фактов, объединяемых единым понятием «акты». Нам представляется, что соотношение понятий «юридические поступки», «акты» и «факты» строится по модели единичного - особенного - общего.

Юридические поступки не исчерпывают всего многообразия актов, как, впрочем, последние не охватывают всех реально существующих фактов. В этом не может быть никакого сомнения, иначе в состав актов оказались бы включенными также события и нормативные условия ${ }^{12}$, то есть неволевые явления, не относимые к событиям, но сходные с ними. Трудность в разрешении поставленной проблемы, следовательно, лежит в плоскости установления признаков, причем, не только общих, но и отличающих юридические поступки от других актов гражданского права, прежде всего и главным образом от сделок, в особенности от односторонних.

В своей психофизической и социально-психической основе сделки и юридические поступки едины. Как указывалось выше, юридические поступки подобно сделкам характеризуются проявлением воли и сознания и представляют собой опосредованную сознанием реакцию организма на определенные раздражители ${ }^{13}$. Одинаков и социально-психологический механизм сделок и юридических поступков. В его основе в обеих разновидностях поведения лежит осознанная потребность, то есть интерес. Будучи разновидностями деятельности человека, рассматриваемые акты служат интересам индивидов, принимая активную форму, необходимую им для удовлетворения потребностей ${ }^{14}$.

Об однотипности психофизического и социальнопсихологического механизмов сделок и юридических поступков свидетельствует еще и то, что способность к совершению тех и других не является врожденным свойством личностей, а приобретается в процессе жиз-

\footnotetext{
${ }^{11}$ Красавчиков О.А. Указ. соч. С. 155.

${ }^{12}$ Ханнанов Р.А. Нормативные условия в динамике гражданского правоотношения / Советское государство и право. 1973. С. 123-127.

${ }^{13}$ Сеченов И.М. Избр. произведения. - М.: 1947. С. 158. 127.

${ }^{14}$ Сеченов И.М. Избр. произведения. - М.: 1947. С. 154.
} 


\section{Право и политика $1(157) \cdot 2013$}

ни. Данная особенность рассматриваемых актов имеет важное практическое значение, ибо указывает не только на необходимость упрочения и развития общественно полезных поступков, но и на возможность предупреждения общественно опасных поступков таким же образом, что и противозаконных сделок.

Итак, юридические поступки так же, как и сделки, являются волеизъявлениями. Это общее между ними. Но в отличие от взаимных и многосторонних сделок, юридические поступки совершаются действиями одной стороны, исходят только от одной стороны. Двух- или многосторонние сделки и поступки - взаимоисключающие понятия. Юридические поступки имеют место там и тогда, где и когда права и обязанности субъектов гражданского права не могут возникнуть из взаимных и многосторонних сделок в силу специфики положения. Так, обнаружение клада невозможно посредством соглашения, ибо клад есть закрытые в земле или скрытые иным способом имущественные ценности, собственник которых не может быть установлен или в силу закона утратил на них право (см. 233 ГК РФ). Наличие договорного способа перехода клада от отчуждателя к приобретателю делает эти ценности объектом договорного правоотношения, а не тем благом, которое лежит в основе правоотношения собственности. Конечно, юридические поступки, не будучи основаниями договорных связей, тем не менее могут сопровождать договорное правоотношение, выступая, например, в качестве меры правоохранительного порядка. Хозяйственная практика прежних лет и отражающее её ныне действующее законодательство подтверждают этот вывод. В соответствии с п. 2 ст. 520 ГК РФ покупатель (получатель) вправе отказаться от оплаты товаров не надлежащего качества, если такие товары оплачены, потребовать возврата уплаченных сумм, впредь до устранения недостатков либо их замены. Являясь нормой, закрепляющей в наиболее общей форме идею, заложенную в семидесятые годы прошлого столетия в постановлении союзного правительства от 27 октября 1967 года ${ }^{15}$ о необходимости борьбы с завышением поставщиком (изготовителем) сортности продукции в документах, удостоверяющих ее качество против действительной, с помощью не только штрафов, но и совершением ряда других действий, направленных на обеспечение его экономических (имущественных) интересов (отказ от продукции и от ее оплаты), она указывает на

${ }^{15}$ СП СССР. 1967. № 26. Ст.186; п.2 ст.520 и п.5 ст. 454 ГК РФ; п. 4 постановления Пленума Высшего Арбитражного Суда РФ от 22 октября 1997 г. №18 «О некоторых вопросах, связанных с применением положений ГК РФ о договоре поставки» // Гражданский кодекс Российской Федерации. С постатейным приложением материалов Конституционного суда РФ, Верховного Суда РФ, Высшего Арбитражного Суда РФ / Сост. Д.В. Мурзин. - 3-е изд., перераб. и доп. - М.: 2004. С. 600 (В дальнейшем Гражданский кодекс. - М.: Норма, 2004). возможность совершения односторонних действий, специально не преследующих цель прекращения возникшего из договора поставки обязательства. До установления факта отгрузки продукции с недостатками, в том числе и с завышенной сортностью, эти действия не предполагаются и не имеются ввиду, ведь по договору ожидается надлежащее исполнение. Правовое значение они приобретают лишь, когда будет установлено надлежащее качество продукции. В противном случае неизбежен был бы абсурдный вывод о допустимости прекращения обязательства поставки даже при наличии ненадлежащего исполнения, что на деле ориентировало бы поставщика на безнаказанное нарушение самого этого обязательства.

Юридические поступки обладают чертами сходства и различия, присущими не только взаимным и многосторонним сделкам, но и односторонним. Последние, как и поступки, проявляют себя односторонне. Так завещание гражданином имущества какой-либо организации (односторонняя сделка) выражает волю только наследодателя, и лишь оно является основанием наследования. Наследодатель без согласия других лиц, то есть по своему усмотрению, устанавливает (изменяет) порядок перехода имущества в собственность гражданина на случай его смерти (ст. 1118 ГК РФ) или собственность государства либо оперативное управление организации-наследника (ст. 1130 ГК РФ). Равным образом отказ от принятия продукции, поставленной с завышенной сортностью (юридический поступок), и от ее оплаты, либо требование ее замены, производится покупателем самостоятельно вопреки желанию поставщика.

Однако, будучи схожими с односторонними сделками по форме проявления, юридические поступки отличаются от них по содержанию волевой направленности. Анализ законодательства и практики его применения показывает, что поступки всегда преследуют экономический или иной фактический результат. Деятельность людей или организаций направлена, прежде всего, на создание и использование определенного блага (а в ряде случаев - на его уничтожение, повреждение, например, при причинении вреда). При этом люди и юридические лица «... целеустремляют свою деятельность отнюдь не на юридические последствия. Их воля направлена на предмет труда - создаваемое благо» ${ }^{16}$. Так, исполняя лежащие на нем обязанности, всякое лицо, в первую очередь, стремится получить встречное удовлетворение, в этих целях совершает ряд фактических действий и ни в коем случае не ставит во главу угла прекращение правоотношения. Здесь прекращение прав и обязанностей, возникших из соответствующих юридических фактов, является субсидиарным обстоятельством по отношению к экономическо-

\footnotetext{
${ }^{16}$ Красавчиков О.А. Указ. соч. С. 154.
} 
му результату, получаемому совершением фактических действий - исполнением. В этой связи представляется правильным мнение О.А. Красавчикова, считающего исполнение одним из видов юридических поступков, и ошибочной точка зрения отдельных исследователей, относящих исполнение к односторонним сделкам ${ }^{17}$. Субъекты гражданского оборота, исполняя лежащие на них обязанности, совершают те или иные действия не в целях погашения правопритязаний, принадлежащих им, a в интересах получения встречного удовлетворения или иного экономического результата. Исполнение правовой обязанности - не самоцель, и производится оно не ради прекращения прав и обязанностей. Предоставляя исполнение, должник совершает те действия (передача имущества, выполнение работ, оказание услуг), которые необходимы для удовлетворения имущественного или иного социально значимого интереса. Эти действия носят фактический характер и имеют место до того, как будет прекращено правоотношение (правовая обязанность). Поскольку действия, совершенные в осуществление права, возникшего из договора или других оснований, уже достигли своей цели в силу исполнения, то и обязательство, как юридическая форма экономического отношения, утрачивает силу, что в дальнейшем и признается законом (ст. 309, п. 3 ст. 328, 408 ГК РФ). Это понятно: бесцельно сохранять правовую оболочку экономического отношения, уже не существующего вследствие исполнения. Исполнение, произведенное надлежащим образом, прекращает обязательство, как сказано в законе, а не формальное прекращение обязательства погашает исполнение. Ошибка В.С. Толстого, как нам кажется, заключается именно в том, что он на первое место ставит юридическую сторону интересующего нас вопроса, забывая о его экономическом содержании и целесообразности.

Направленность исполнения на экономический или иные неправовые результаты делает его специфической стадией в динамике правоотношения, особой неюридической формой прекращения обязательства, приобретающего правовое значение лишь в будущем, что ясно видно хотя бы из следующего примера с прекращением договора поручения. В ст. 978 ГК РФ сказано, что если договор поручения прекращен до того, как поручение исполнено полностью, доверитель обязан возместить поверенному понесенные издержки. Тем самым закон отдает предпочтение экономическому содержанию правоотношения, а не его форме, так как доверитель обязывается возместить последнему убытки за несовершение действий, предназначенных удовлетворить его интерес, а не за совершение

${ }^{17}$ Толстой В.С. Исполнение обязательств. - М.: 1973. С. 23-25; Денисевич Е.М. Односторонние сделки в гражданском праве Российской Федерации: понятие, виды, значения. Автореферат дисс. канд. юрид. наук. - Екатеринбург.: 2004. - 25 с. действий по оформлению факта прекращения обязательства (дополнительного соглашения).

Не случайно в ГК бывших союзных республик нормы об исполнении обязательств представлялись (излагались) раньше, чем положения о прекращении обязательств.

Этим приемом законодательной техники подчеркивалась значимость исполнения в развитии правоотношения. Учтено то, что субъективное право лица должно быть реализовано, а отнюдь не прекращено без удовлетворения того интереса, ради которого оно было предоставлено.

Поэтому исполнение становится юридически значимым обстоятельством лишь после того, как оно фактически заимеет место. До фактического исполнения беспредметна постановка вопроса о прекращении обязательства надлежащим исполнением (п. 1 ст. 408 ГК РФ). В связи со сказанным глава ХХІХ ГК РФ должна найти свое закрепление в структуре ГК РФ раньше, чем глава XXVI.

Таким образом, как видно из изложенного, юридические поступки отличаются от односторонних сделок по содержанию волевой направленности, являющейся главным признаком, лежащим в основе отграничения поступков и от других видов гражданско-правовых актов.

Поэтому совершенно правильно утверждение M.M. Агаркова о том, что в юридических поступках «...отсутствует характерный для сделок момент зависимости между юридическим эффектом и направленным на него содержанием воли субъекта» ${ }^{18}$.

Здесь уместно обратить внимание на позицию В.Ф. Яковлева, который, так же, как и Н.Н. Агарков, нацеливает на необходимость учета при осуществлении правовой и научной деятельности различий между фактом-поступком и юридическим поступком, когда он пишет, что « ...обязательственное право допускает и одностороннее распоряжение правом (возникшим, существующим правом. - Прим. мое. Р.А. Ханнанов), если не затрагиваются интересы контрагента (уступка требования, зачет встречного требования) или в полной мере обеспечивается их соблюдение возмещением убытков, либо в случаях противоправного поведения другой стороны» ${ }^{19}$. Дело в том, что одностороннее распоряжение правом в указанных случаях всегда затрагивает те или иные интересы контрагента. Новый кредитор, быть может, организационно не готов к приёму исполнения обязательства, он обременен дополнительными формальностями, предусмотренными ст. 389 ГК РФ, совершать действия, являющиеся необычными для первоначального кредитора, претерпевать зачет нежелательного для него в данном конкретном случае встречного требования к первоначальному кредитору и.т.д. и.т.п. И при зачете встречного однородного требо-

\footnotetext{
${ }^{18}$ Агарков М.М. Указ. соч. С. 95.

${ }^{19}$ Яковлев В.Ф. Гражданско-правовой метод регулирования общественных отношений. 2-е изд., доп. - М.: 2006. С. 202-203.
} 


\section{Право и политика $1(157) \cdot 2013$}

вания (ст. 410 ГК РФ) затрагиваются интересы сторон, не получивших ожидаемого или предусмотренного в договоре удовлетворения согласно правилу ст. 309 ГК РФ об исполнении обязательства надлежащим образом в соответствии с условиями обязательства.

Не следует забывать и то, что стороны обязательства, как правило, не включают в договор условия об уступке требования или о зачете. Действия по их выбору и применению (факты-поступки) совершаются исключительно по их усмотрению и лишь при возникновении соответствующих потребностей, вызванных неправовыми (экономическими, социальными) причинами. Правовые последствия они вызывают в силу самого факта (IPSO FACTO) и в виде недостающего элемента юридического состава, входя в основание изменения или прекращения обязательственного правоотношения в силу закона (IPSO JURE). До наступления такого момента преобразования названные действия юридически безразличны и не могут вызывать правовые последствия, в том числе и в виде одностороннего распоряжения правом. Правовое значение их состоит в создании юридической возможности совершения одностороннего акта, изменяющего или прекращающего правоотношения, секундарного правомочия, то есть обстоятельства, не обладающего свойством притязания, которому, как правило, не корреспондирует конкретная обязанность, но который позволяет управлять правовой связью в условиях изменяющихся фактических обстоятельств ${ }^{20}$.

При анализе правовой природы юридических поступков можно использовать и другие отличающие их от юридических актов признаки.

Юридические поступки отличаются от сделок тем, что они представлены действиями не только правомерными, но и неправомерными. Подтверждением сказанного являются действия, направленные на причинение вреда (гл. 59 ГК РФ) и на неосновательное обогащение (гл. 60 ГК РФ). Укоренившееся в юридической литературе мнение о том, что юридическими поступками являются лишь правомерные действия, предвзято и надумано. «Юридические поступки - это такие правомерные действия, которые порождают гражданско-правые последствия независимо, а иногда и вопреки намерению человека, совершившего юридический поступок», - пишет Н.Д. Егоров ${ }^{21}$. Позиция Н.Д. Егорова, как, впрочем, и позиция В.С. Толстого небесспорна, так как при определении понятия юридических поступков исходит не из социально-экономической сущности последних, не из того, что юридические поступки - это, прежде всего, поступки, содержанием которых

${ }^{20}$ Исаков В.Б. Юридические факты в советском праве. - М.: 1984. C. 82.

${ }^{21}$ Гражданское право. Учебник. Часть 1. Издание 3, перераб. и доп./ Под ред. А.П. Сергеева, Ю.К. Толстого. - М.: 1998. С. 91. охватываются фактические действия, совершаемые независимо от их правового опосредования, от соответствия требованиям норм права, от их дозволенности и запретности. Юридическими они становятся, опять же, лишь после получения правовой оценки в форме позитивного или негативного законодательного, административного и судебного признания. Здесь законодатель, как нам представляется, учитывает еще и то обстоятельство, что субъекты гражданских связей совершают не только действия, заранее предусмотренные законом, но и иные действия, которые оказывают на гражданские отношения определенные воздействия.

Н.Д. Егоров подменяет фактические действия, направленные на неправовой результат, действиями, получающими в дальнейшем юридическую оценку. При отсутствии первых не может быть и последних.

Если исходить из такого понимания сущности юридических поступков и в данном контексте представить правоотношение, развивающееся на их основе, то нетрудно заметить, что юридические поступки отличаются от других юридических актов в плане последовательности их наступления во времени. В ходе формирования и развития гражданского правоотношения иные действия, приобретшие в дальнейшем правовое признание в качестве юридических поступков (содержание), всегда предшествуют своей правовой форме (юридическому факту). Эти действия (поступки какакты реальной действительности), появляясь во времени раньше, чем сами станут юридическими обстоятельствами, т.е. юридическими фактами, превращают реальную возможность наступления последних в действительность. Тем самым они обуславливают порождение и развитие гражданских прав и обязанностей участников правоотношения. Указанная черта, обнаруживаемая в процессе анализа правовой сущности, является одной из разграничительных особенностей, дающих возможность отличать юридические поступки от других юридических фактов.

Сделки - всегда правомерные действия. От административно-плановых актов они отличаются по характеру вызываемых ими связей. Юридические поступки, как правило, сопряжены с отношениями координации, тогда как первые, преимущественно, вызывают отношения субординации. Судебно-арбитражные и семейные акты выделяются из области правовых поступков особой сферой их существования.

Резюмируя изложенное, можно дать следующее определение юридических поступков: под юридическими поступками понимаются иные односторонние акты физических и юридических лиц, направленные на экономические, социальные или другие неправовые результаты, в силу закона вызывающие правовые последствия.

Данное определение, на наш взгляд, правильно раскрывает природу юридических поступков и их содержа- 
ние, отмечает значимость этих обстоятельств для экономики и права и указывает на сферу их существования, расширяя круг фактов, относимых к поступкам.

Юридическим поступкам присущи и другие разграничительные особенности (свойства, черты), разъясняющие в известной степени их правовую природу как динамичных явлений действительности. Прежде всего, это их тесная связь с нормативными условиями ${ }^{22}$.

На наличие явлений, не укладывающихся в систему общей классификации юридических фактов, тем не менее обуславливающих определенные правовые последствия и выступающих в виде предпосылок для наступления (формирования) правоотношений либо создающих условия для их возникновения и т.п., ряд ученых уже обращал внимание. К такого рода явлениям они относили свойства вещей (неделимость, потребляемость, принадлежностный характер) ${ }^{23}$, характер вещей (служебный характер жилого помещения ${ }^{24}$, развитие обстоятельств (стечение тяжелых обстоятельств $)^{25}$ и т.д. Эти явления признавались ими самостоятельными юридическими фактами. Однако подобное понимание их юридической природы в некоторой степени представляется неточным и может быть принято с отдельными оговорками. Юридическими фактами они становятся лишь в том случае, когда играют роль недостающего элемента, необходимого составляющего сложного юридического состава правоотношения. Свойства подобного рода, обуславливающие направленность юридических поступков на экономические или иные неправовые результаты, самостоятельных правовых последствий не порождают.

Эти последствия наступают лишь вкупе с самими юридическими поступками. Другими словами, реальные действия участников гражданского оборота (поступки) квалифицируются юридическими и приобретают правовое значение в присутствии факта особой атрибутивности указанных поступков - их направленности на названные результаты. Тем самым и рассматриваемые свойства, не охватывающие юридическую сторону волевого опосредования гражданских отношений, обуславливают наступление волевых правовых обязательств - юридических поступков, т.е. юридических фактов, становясь одним из элементов оснований возникновения и движения гражданских прав и обязанностей. В условиях организации гражданской деятельности физических и юридических лиц на принципах социальной и экономической свободы,

22 Ханнанов Р.А. Нормативные условия в динамике гражданского правоотношения / Советское государство и право. 1973. №8. C. 123-127.

${ }^{23}$ Иоффе О.С. Указ. соч. С. 122.

${ }^{24}$ Толстой Ю.К. Указ. соч. С. 17.

${ }^{25}$ Советское гражданское право. Учебник в 2-х томах. Т.1. - М.: 1968. С. 271-272; Савостин В. Юридическое состояние. - М.: 1999. решения возникающих при этом вопросов собственным усмотрением, своей волей и в своем интересе, дальнейшее правовое обеспечение возникновения, упрочения и стимулирования поступков, обладающих признаками направленности на общеполезные социально-экономические и иные неправовые результаты приобретает важное общенародное и общегосударственное значение.

Как отмечалось выше, рассматриваемые свойства поступков (направленность на неправовой результат), не порождая самостоятельных правовых последствий, однако, способны оказать известное юридическое воздействие на регулируемые правом общественные отношения, обуславливая возникновение и развитие юридических фактов, называемых юридическими поступками. В этом смысле они создают состояние связанности последних в проявлении их активности, в вызове к жизни предусмотренного нормами права эффекта. Правовые возможности, наступающие вследствие реализации сложных составов, состоящих из свойств поступков, направленных на неправовой результат и «активизированных» благодаря им юридических поступков, могут быть превращены в действительность. Во многих случаях именно в силу таких неправовых обстоятельств наступают завершенные правовые последствия. Примеров этому достаточно. Так, согласно ч. 2 п. 1 ст. 220 ГК РФ переработчик материалов, действующий добросовестно (свойство) приобретает право собственности на новую вещь (правовое последствие); в соответствии с п. 1 ст. 234 ГК РФ лицо, не являющееся собственником имущества, добросовестно, открыто и непрерывно (свойства) владеющее как своим собственным недвижимым имуществом в течение пятнадцати лет либо в течение пяти лет, приобретает право собственности на это имущество (правовое последствие) ${ }^{26}$. Здесь свойство поступков, направленных на неправовые (экономические) результаты (добросовестность, открытость, непрерывность) входят в юридический состав оснований возникновения и движения гражданских правоотношений и, только входя в этот состав в качестве элемента, становятся юридическими фактами. Следует, однако, иметь в виду и то, что юридические поступки, поскольку они имеют место в жизни или в силу неправовых обстоятельств становятся таковыми, всегда являются самостоятельными юридическими фактами. Например, поступки, предусмотренные п. 5 ст. 252 ГК РФ, согласно которому лицо, получившее денежную компенсацию (поступок) при разделе имущества, находящегося в долевой собственности и выдела из него доли, теряет право собственности на дом. Точно так

\footnotetext{
${ }^{26}$ См.практику Верховного суда РФ / п.14 постановления Пленума Верховного Суда РФ от 23 апреля 1991 г. №2 «О некоторых вопросах, возникших у судов по делам о наследовании» (в ред. постановлений Пленума Верховного суда РФ от 21 декабря 1993 г. №11 и от 25 октября 1996 г. №10) / Гражданский кодекс РФ. С.338.
} 


\section{Право и политика $1(157) \cdot 2013$}

же полученные в результате деятельности крестьянского (фермерского) хозяйства (поступки) плоды, продукция и доходы влекут появление права совместной собственности на эти ценности у членов хозяйства (п. 3 ст. 257 ГК РФ). Владелец земельного участка, не являющийся собственником, не вправе распоряжаться эти участком, если иное не предусмотрено законом или договором (п. 3 ст. 264 ГК РФ). С истечением срока пользования земельным участком право пользования им должно быть прекращено (п. 3 ст. 610 ГК РФ), и землепользователь не может передать спорный участок третьему лицу ${ }^{27}$.

Таким образом, юридические факты, будучи предусмотренными в норме права, как и любое правовое явление, имеют свое специфическое правовое содержание. Таким содержанием является основанная на гражданском законе и обусловленная неправовыми обстоятельствами или самостоятельная возможность возникновения, изменения и прекращения субъективных прав и обязанностей.

Иные действия физических и юридических лиц, относящиеся к юридическим поступкам, закреплены в обширном круге норм гражданского права. В зафиксированности в законодательных актах находит свое выражение их правовое основание. В качестве иллюстрации такого вывода можно сослаться на значительное число статей любого гражданско-правого нормативного акта. В одном только ГК РФ они предусмотрены ст. 5, пунктами $5,6,8$ ч. 2 ст. 8 , абз. 6 ст. 12 , ст. ст. $13,14,16$, п. 2 и п. 5 ст. 19, ст. 23 , п. 1 ст. 27 , п. 1 ст. 30 , п. 1 ст. 38 , ч. 1 ст. 42 , п.п. $1 ., 2$ ст. 45 , ст. 50 , ст. 65 , абз. 1 ст. 101 , ст. 107 , ст. 117 , ст. 118 , ст.121, ст. 128 , ч. 1 ст. 134 , ст. 135 , ст. 148 , ст. 151 , ст. 152 , ст. 162 , ст. 165 , ст. ст. 177,178 , п. 1 ст. 178 , ст. 189 , п. 2 ст. 209 , ст. ст. $217,218,219$. ст. ст. $220,221,225$, ст. 227 , ст. ст. 233,234, п. 1 ст. 235 , ст. 240 , п. 3 ст. 245 , ст. 247 , абз. 3 ст. 256 , п. 3 ст. 257 , п. 3 ст. 261 , ст. 262 , п. 3 ст. 263 , п. 2 ст. 269 , ч. 2 п. 1 ст. 271 , ст. ст. 286,287 , ст. 293 , ст. 309 , ст. 320 , ст. 327 , п. 1 ст. 334 , ст. 359 , п. 2 ст. 365 , ст. ст. 374 , 375, ст. 397 , абз. 2 ст. 398 , п. 1 ст. 408 , ст. 410 , ст. 415 , ст. 431, ст. 451, п. 2 ст. 455 , ст. 466 и др.

Все эти и другие статьи ГК РФ содержат указания на внешние обстоятельства, относимые к действиям, самостоятельно или в совокупности с некоторыми явлениями, направленными на неправовой результат, вызывающими правовые последствия: возникновение, изменение и прекращение гражданских прав и обязанностей.

Рассмотрение вопроса о юридических поступках представляет интерес постольку, поскольку они в большинстве своем обусловлены так называемыми норма-

\footnotetext{
27 Пункт (В дальнейшем П.) 6 приложения к информационному письму Президиума Высшего Арбитражного суда РФ от 27 февраля 2001 г. №61 «Обзор практики применения арбитражными судами земельного законодательства» / Гражданский кодекс РФ. C. $265-266$.
}

тивными условиями, выполняющими роль предпосылок наступления юридических фактов (возведения их в ранг юридических фактов), и существует опасность смешения их при установлении оснований гражданских правоотношений, определении места каждого из них в механизме гражданско-правового регулирования. Это во-первых. Во - вторых, правовая норма может и не содержать указания на названные условия, ограничиваясь акцентом на завершающем сложный юридический состав факте либо ссылкой на обычаи делового оборота (ст. 5 ГК РФ).

Характерным в этом отношении является дело по спору, вытекающему из внешнеторговой сделки между иностранной фирмой (поставщиком) и Российским торговым предприятием (покупателем) об изменении контракта в части базиса поставки (СИФ на ФОБ). Учитывая, что покупатель никаким письменным документом своего согласия изменить договор не подтверждал, и, следовательно, договор остался неизмененным, Высший арбитражный суд РФ подтвердил право арбитражного суда принимать решение на основе обычаев делового оборота, касающихся базиса поставки в сфере международной торговли (в редакции «Инкотермса») в том случае, когда стороны договорились об их применении или изменили соглашение в письменной форме ${ }^{28}$. Такая позиция арбитражных судов, как нам представляется созвучна с содержанием норм п. 1 ст. 8 ГК РФ и подпункта 8 части 2 п. 1 ст. 8 ГК РФ. Вопрос о том, назвать (включить) юридические поступки в гипотезы норм права или нет, решается законодателем исходя из важности регулируемых (охраняемых) этими нормами общественных отношений в интересах обеспечения и укрепления законности и правопорядка. Уместно отметить и то, что в условиях рыночной организации социальноэкономической жизни и обилия вопросов, решаемых усмотрением, законодательная фиксация всего многообразия повседневно возникающих гражданско-правовых поступков нецелесообразна. Вполне возможно, что стремление легализации всех поступков может лишить присущего им главного достоинства - усмотрения. Без последнего поступки могут стать препятствиями на пути развития гражданских правоотношений.

\section{3. Классификация гражданско-правовых поступков.}

Общеизвестно, что в основе понятия классификации лежат латинские слова classis (разряд) и facio (делаю, раскладываю). Отсюда под классификацией подразумевается система соподчиненных категорий какой-либо области

\footnotetext{
28 П. 2 Приложение к информационному письму Президиума Высшего Арбитражного Суда РФ от 16 февраля 1998 г. № 29 «Обзор судебно-арбитражной практики разрешения споров по делам с участием иностранных лиц» / Гражданский кодекс. М.: Норма, 2004. С. 22.
} 
знания или деятельности человека, используемая как средство установления существенных связей между этими категориями (понятиями или классами) объектов, достижения точной ориентировки в многообразии понятий соответствующих объектов.

Классификация неразрывно связана с категорией системности понятий или объектов. Она, взятая в целом и в единстве, представляет собой сложное явление в виде определенной системы, имеющей свою структуру, внутренние закономерные связи между элементами, входящими в совокупность (множество) понятий и объектов, отношения, определяющие место и свойства последних. В этом контексте классификация является средством хранения и эффективного поиска информации, содержащейся в ней самой. Главное в ней - отражение объективных законов реальной действительности, присущих ее отдельным областям, сферам, участкам, фрагментам, которые обуславливают зафиксированные в классификации свойства и связи объектов. Систематизация, охватываемая классификацией, учитывает тот факт, что в жизни (материи) нет строгих разграничений категорий, понятий и объектов и переходы от одного класса к другому - не случайность, а неотъемлемое закономерное свойство действительности. Такие переходы возможны лишь при условии теоретического осмысления многообразия накопленных в ходе жизнедеятельности фактов, в свою очередь позволяющих выдвинуть обоснованные прогнозы относительно неизвестных еще закономерностей и обстоятельств, в конечном счете призванных обеспечивать социально-экономический (общественный) прогресс. В стране, в условиях измененного общественного строя, продолжающегося реформирования и модернизации экономики, перевода ее на инновационный путь развития разработка оптимальной классификации понятий и объектов реальной действительности, в частности, касающейся пересмотра направлений и содержания хозяйственной деятельности, становится первой народнохозяйственной важности.

С этой общенаучной позиции следует исходить и в научно-практическом обосновании юридических поступков как составной части учения о юридических фактах.

Необходимость классификации поступков, относящихся к сфере способа производства, к области жизнедеятельности человека предопределяется объективно существующей потребностью в целеполагании. Производство материальных благ, равно как и организация и управление им, не могут иметь место без осознания сущности и содержания будущих, настоящих и прошлых поступков, оценки их результатов, выбора направлений и постановки целей соответствующих действий с позиций желательности, результативности и выгодности. Нельзя забывать и другой аспект проблемы, закономерно проявляющей себя в виде нужды в создании порядка изо дня в день совершающихся актов производства и обмена, в форме общественного регулирования.

Сообразно этому классификация юридических поступков как юридической формы самих поступков обуславливается природой связей гражданского, прежде всего имущественного оборота и необходимостью уровневого упорядочения на принципах системности (структурности, взаимосвязанности, целостности, единства). Как нам представляется, существующие до сего времени дефиниции не полно учитывают требования сферы жизнедеятельности человека, его коллективных организационных образований, многообразия совершаемых ими поступков и закономерностей бытия последних, невозможности их функционирования без государственного и правового регулирования. В результате этого необоснованно суживается круг поступков, могущих быть признанными юридическими.

Исходя из вышеизложенного можно предложить следующую классификацию юридических фактов, построенную на базе следующих критериев (оснований):

1. по направленности воли участников общественных отношений на определенный результат. Внимательный анализ гражданского законодательства и практики его применения показывает, что поступки как действия (бездействия), направленные на экономический или иной фактический результат, оказывают на объект правоотношения либо непосредственное, либо же отдаленное воздействие. Если поступки своим содержанием опосредствуют прямой экономический результат и выражаются в действиях материального характера (создание, потребление, изменение, перемещение и т.д. материальных благ), то их целесообразно назвать материальными. Когда же поступки не сопряжены с непосредственным экономическим эффектом и выражены в действиях нематериального, иного фактического порядка (обеспечение условий для создания, потребления, изменения и т.д. материальных благ, а также формирование, приобретение, передача и т.д. нематериальных благ), следует именовать их нематериальными.

Деление поступков на материальные и нематериальные по их экономическому содержанию является главным разграничительным признаком, отличающим их друг от друга. Оно имеет важное теоретическое и практическое значение, т.к. позволяет правильно учитывать особенности каждого поступка в правотворческой деятельности, в частности, в сконструировании хозяйственных прав и обязанностей организаций, и, следовательно, достичь рационального использования этих прав и обязанностей в интересах дальнейшего развития экономики.

2. по ареалу распространения в реальной действительности (сфере бытия), охватывающие область:

- экономики (промышленность; сельское хозяйство и АПК; капитальное строительство; материально-техническое обеспечение (снабжение); производственно-техниче- 


\section{Право и политика $1(157) \cdot 2013$}

ское обслуживание; транспорт; связь; финансирование и банковское обслуживание и др.);

- социальной жизни (социальное обеспечение и социальное страхование; медицинское страхование; трудоустройство; культура; государственное и муниципальное управление; гуманитарное образование; интеллектуальная деятельность в сфере литературы, науки и техники, искусстве и т.п.).

Характерным для этой сферы поступков является то, что они, как правило, изначально не будучи предусмотренными законом или иными нормативными актами в качестве таковых, все же находят в дальнейшем свое правовое признание и юридическую защиту. Если правила, содержащиеся в части первой настоящей статьи (ст. 431 ГК РФ. Толкование договора. Прим. мое. - Р.Х.), не позволяют определить содержание договора, должна быть выяснена действительная общая воля сторон с учетом цели договора. При этом принимаются во внимание все соответствующие обстоятельства, включая предшествующие договору переговоры и переписку, практику, установившуюся во взаимных отношениях сторон, обычаи делового оборота, последующее поведение сторон, как сказано в законе. Здесь не может быть сомнений в том, что перечисленные в статье закона поступки признаются, поскольку они уже совершены, юридическими и подлежат правовой защите, что подтверждается и практикой рассмотрения споров арбитражными судами России ${ }^{29}$.

3. по их связи с действующим правом в форме (разновидности):

- поступков, предусмотренных конкретными нормами закона, им зафиксированных (создание недвижимого имущества - ст. 219 ГК РФ; переработка - ст. 220 ГК РФ; сбор или добыча общедоступных вещей и животных - ст. 221 ГК РФ; отказ от принадлежащей собственнику вещи - ст. 225 ГК РФ; находка - ст. 227 ГК РФ; обнаружение клада - ст. 233 ГК РФ; приобретение имущества по истечении давностного срока - 234 ГК РФ; исполнение обязательств и др.);

- поступков, предопределенных общими нормами закона, нормами-принципами (определение любых, не противоречащих законодательству условий договора -

${ }^{29}$ П.1.Приложения к письму Президиума Высшего Арбитражного Суда РФ от 28 ноября 1996 г. № С2-7 / ОП-706 «Обзор отдельных постановлений Президиума Высшего Арбитражного Суда Российской Федерации по спорам, связанным с расчетами (без участия банков)»; п.6 Приложения к информационному письму Высшего Арбитражного Суда РФ от 28 сентября 1999 г. №47 «Обзор практики рассмотрения споров, связанных с применением Закона РФ «Об авторском праве и смежных правах»; п.1. Информационного письма Президиума Высшего Арбитражного Суда РФ от 29 сентября 1999 г. №48 «О некоторых вопросах судебной практики, возникающих при рассмотрении споров, связанных с договорами по оказанию правовых услуг» / Гражданский кодекс. - М.: Норма, 2004. C. $524-525$. п. 2 ст. 1 ГК РФ; свободное перемещение товаров на всей территории РФ - ч. 2 п. 3 ст.1 ГК РФ; вступление в имущественные связи (хозяйственные отношения), основанные на равенстве, автономии воли, самостоятельности - п.1 ст. 2 ГК РФ); совершение действий, охватываемых понятием обычаев делового оборота - ст. 5 ГК РФ; оценка поведения субъектов гражданского (хозяйственного) оборота по аналогии закона ${ }^{30}$ или по аналогии права и соответствие требованиям добросовестности, разумности и справедливости - ст. 6 ГК РФ; возникновение гражданских прав и обязанностей вследствие совершения иных действий - п.8 ст.8 ГК РФ; защита гражданских прав исходя из принципа разумности и добросовестности - п. 3 ст. 10 ГК РФ; самозащита гражданских прав - ст. 14 ГК РФ; выбор иных имущественных и личных неимущественных прав - ст. 18 ГК РФ; предпринимательская деятельность ст. 23 ГК РФ и др;

- поступков, не предусмотренных законами, а признаваемых ими в качестве таковых и в силу этого получающих правовую защиту. Круг данной подгруппы поступков всецело предопределяется потребностями социально-экономического развития всех сфер жизнедеятельности человека. В ряде случаев, под «давлением обстоятельств» или «разрядки конфликтной (спорной) ситуации» подобные поступки могут совершаться целенаправленно на правовой результат, хотя изначально они и были предприняты в ожидании социального, экономического и другого позитивного результата. Изменение обстановки (clausula rebus sic stantibus) заставляет участников гражданских отношений прибегнуть к такому исходу дела. «Гражданский кодекс РФ не решает вопрос о том, вправе ли сторона, для которой заключение договора обязательно, передать разногласия по договору на рассмотрение суда, однако если они переданы, а контрагент представил в суд свои предложения по условиям договора (поступки в форме выбора способа защиты права. Прим. мое. - Р.Х.), то в этом случае арбитражный суд должен исходить из того, что спор передан на его рассмотрение по соглашению сторон», - сказано в п. 1 Приложения к информационному письму Президиума Высшего Арбитражного Суда РФ от 5 мая 1997 г. №14 «Обзор практики разрешения споров, связанных с заключением, изменением и расторжением договоров».

Позиция Президиума Высшего Арбитражного Суда РФ как направленная на обеспечение нормального хозяйственного процесса является абсолютно верной.

\footnotetext{
${ }^{30}$ Характерным в этом отношении является практика признания недействительными размещения заказов иными способами, чем проведение торгов, руководствуясь аналогией закона (п. 2 ст.449 ГК) / Тарабаев П. Некоторые вопросы защиты прав участников размещения товаров, выполнения работ, оказания услуг для публичных нужд / Хозяйство и право. 2006 г. №3. С. 26-29.
} 
4. по вызываемым правовым последствиям:

- поступки, соответствующие действующим законодательным (правовым) нормам, и

- поступки, не соответствующие таким нормам.

Иначе говоря, необходимо различать поступки правомерные и неправомерные (независимо от того, являются ли они материальными или нематериальными). Первая группа поступков входит в совокупность оснований множества гражданских прав и обязанностей с положительным экономическим содержанием.

Поэтому совершение их всячески поощряется законом и практикой рыночных условий хозяйствования. Другая группа поступков, как правило, сопряжена с результатами отрицательного характера и входит в круг оснований правоохранительных правоотношений. Государство не заинтересовано в появлении таких поступков и принимает меры по искоренению их.

Создание предпосылок для возникновения, упрочения и развития правомерных поступков - одна из предпосылок успешного развития экономики. Равным образом устранение неправомерных поступков рассматривается государством как важнейшее условие укрепления правопорядка.

К числу интересующих нас явлений относятся многообразие актов физических и юридических лиц, таких, как правомерные, так и неправомерные действия. В качестве аргумента в пользу сказанного достаточно сослаться на такое неправомерное действие, обычно называемое проступком, как причинение вреда имуществу другого лица. Практически трудно представить ту ситуацию, когда причинитель вреда, посягая на имущество другого лица, повреждая или уничтожая его, преследовал бы цель взять на себя обязанность возместить противоправно причиненный вред, т.е. породить обязательство из причинения вреда.

Здесь правонарушителем двигают скорее другие мотивы и побуждения (месть, корысть и т.п.), т.е. совсем иные причины. Для него, в конечном счете, более важен отрицательный социально-экономический результат (умаление имущественных благ другого лица), чем создание нежелательного для него самого правоотношения. Последнее, мыслимо разве что теоретически и как исключение из общего.

В равной степени представляется ошибочным свести к юридическим поступкам одни лишь действия. К ним с полным основанием можно отнести также и бездействия. Вряд ли может вызвать сомнения тот факт, что всякое неосторожное бездействие есть поступок. Таковы, например, упущения ${ }^{31}$. Кроме того, круг юридических поступков может быть расширен также за счет некоторых умышленных форм. В качестве примера достаточно назвать

${ }^{31}$ Ханнанов Р.А. Правовая природа бездействия и каузальность. // Советское государство и право. 1978. №4. С. 124-128. не только один поступок - неисполнение обязательства (ст. ст. 217 и 218 ГК РФ), т.е. несовершение действия, но и ряд других поступков (неоднократная невыборка товаров, влекущая односторонний отказ от исполнения договора поставки - абз. 2 п. 3 ст. 523 ГК РФ $\Phi^{32}$, несовершение распорядительных сделок с валютными ценностями, неиспользование иностранной валюты как средства платежа ${ }^{33}$ и т.п. бездействия). Поэтому юридическими поступками правильно будет признать любые односторонние акты субъектов гражданского права независимо от форм их проявления (выражения), если они создали или даже способны создать неправовые результаты, которые сопровождаются правовыми последствиями в силу закона.

Все поступки, относятся ли они к материальным или нематериальным, а также являются ли они правомерными или неправомерными, могут быть разграничены и по другим признакам (критериям). Для гражданского оборота важно деление поступков на подгруппы по направленности воли лиц, их совершающих, на тот или иной конкретный результат, ибо не будучи устремленными на достижение каких-либо правовых последствий, поступки обязательно совершаются с известной целью удовлетворять определенные интересы людей. Исходя из этого признака следует различать поступки, опосредствующие: а) создание, изменение, потребление материальных объектов (например, производственная деятельность, творчество); б) передачу имущества, выполнение работ, оказание услуг (исполнение обязательства); в) уведомление о фактах и признание фактов; г) реализацию и самозащиту субъективных интересов (необходимая оборона, крайняя необходимость, выбор мер по охране имущества и т. д.).

Такова система поступков, имеющих гражданскоправовое значение. В зависимости от целей предпринятого исследования могут быть рекомендованы деления поступков по самым различным основаниям. Но предлагаемая классификация, на наш взгляд, в достаточной степени характеризует место поступков в рамках учения о юридических фактах гражданского права.

\footnotetext{
32 П. 20 постановления Пленума Высшего Арбитражного Суда РФ от 22 октября 1997 г. №18 «О некоторых вопросах, связанных с применением положений Гражданского кодекса РФ о договоре поставки» / Гражданский кодекс РФ. С. 395-396.

${ }^{33}$ П. 17 информационного письма Президиума Высшего Арбитражного Суда РФ от 31 мая 2000 г. №52 «Обзор практики разрешения арбитражными судами споров, связанных с применением законодательства о валютном регулировании и валютном контроле» / Гражданский кодекс. - М.: Норма, 2004. С. 395-396; п. п. 1-14 информационного письма Президиума Высшего Арбитражного суда РФ от 4 ноября 2002 г. №70 «О применении арбитражными судами статей 140 и 317 Гражданского кодекса Российской Федерации». / Комментарий к Гражданскому кодексу Российской Федерации. Части I, II, III, IV. Составитель А.Б. Борисов. - М.: Книжный мир, 2009. С. 168-170.
} 


\section{Право и политика $1(157) \cdot 2013$}

Она дает ключ к раскрытию значения поступков в динамике прав и обязанностей субъектов гражданского права.

\section{4. Социально-экономическое и юридическое значение поступков в условиях перехода России на инновационный путь развития.}

Существование гражданско-правовых поступков объективно обусловлено многообразием общественных отношений и наличием комплекса обстоятельств, порождающих, изменяющих или прекращающих социально-экономические связи, т.е. реальных фактов. Категория поступков охватывает собой разнообразные формы деятельности людей и их коллективов. По этому поводу О.А. Красавчиков писал: «Работа на заводе и в школе, в колхозе и консерватории, в технической лаборатории и за столом писателя - все это, с правовой точки зрения, юридические поступки. В них деятельность рабочего и учителя, колхозника и музыканта, изобретателя и писателя направлена, в первую очередь, на создание определенного блага» ${ }^{34}$. В этом высказывании довольно четко и образно очерчен круг поступков и их значение в социально-экономической жизни нашего общества.

Значение поступков в обществе не может быть рассмотрено без выяснения их роли в отдельных специфических областях человеческой деятельности: в сфере обеспечения личного благосостояния людей, удовлетворения их материальных и культурно-бытовых потребностей, а равно в экономической жизни страны.

В условиях существования товарно-денежных отношений организация производства материальных благ осуществляется отдельными, обособленными производителями, специализирующимися на выработке одного какого-либо продукта ${ }^{35}$. Это предопределяет сложность процесса обмена и распределения материальных благ, невозможность, а иногда и нецелесообразность социальной регламентации государством хозяйственного механизма во всех его подробностях. В силу этого руководство экономикой страны, ее отраслями производится в различных формах: прогнозирования, экономического стимулирования, а также гарантирования инициативы и самостоятельности хозяйствующих субъектов, повышения материальной заинтересованности работодателей и работников в результатах их труда. Использование различных форм управления хозяйством увеличивает сферу действия товарно-денежных отношений в экономике, обеспечивает появление новых видов этих отношений на основе фактических обстоятельств, усиление влияния последних на производство.

\footnotetext{
${ }^{34}$ Красавчиков О.А. Указ. соч. С. 54.

${ }^{35}$ Ленин В.И. Полн. собр. соч. Т. 1. С. 86-87.
}

Развитие товарно-денежных отношений является сложным диалектическим процессом, в котором переплетаются различные тенденции, даже подчас противоположные, вызванные различными фактами реальной действительности. К их числу относятся, прежде всего, специализация и кооперирование производства, которые и в настоящее время остаются важнейшими путями его развития. Эти пути одинаково необходимы для всех отраслей экономики. Специализация и кооперирование сопровождаются установлением между предприятиями и предпринимателями хозяйственных связей, объективно, в силу действия закона стоимости, могущих сложиться лишь в форме товарно-денежных отношений. Эти связи вызываются к жизни причинами фактического порядка. Связи, возникшие на основе фактических обстоятельств, и, разумеется, сами эти обстоятельства, расширяют возможности рационального использования товарно-денежных отношений, создания материально-технической базы общества в условиях развития его на принципах рыночной организации производства. Известно, например, создание подобных возможностей под воздействием таких обстоятельств, как накопление предприятиями значительной части прибыли и распоряжение ею по их собственному усмотрению для создания поощрительных фондов, направленных на материальное поощрение, социально-культурные мероприятия и развитие производства, обеспечение самостоятельности и автономии предприятий (п. 2 ст. 1 ГК РФ) в области организации и осуществления производства, реализации продукции и т.д. Аналогичного рода поступки товаропроизводителей, направленные на экономический результат, в дальнейшем находят свое юридическое закрепление.

Воздействие товарно-денежных отношений на производство через посредство фактических обстоятельств имеет место не только в процессе специализации и кооперирования, обеспечения самостоятельности и инициативы товаропроизводителей, но и в ходе установления самой производственной программы юридических и физических лиц. Сказанное касается, в первую очередь, сельского хозяйства и АПК, пищевой и легкой промышленности, поскольку в прогнозировании их деятельности, особенно во внутрихозяйственном планировании ${ }^{36}$ возрастающее значение приобретают заказы потребителей. Порожденные практикой работы предприятий промышленности и торговли советского периода, первоначально опосредующие лишь экономические связи между ними, заказы (или портфель заказов) и в дальнейшем должны найти достойное место на практике и свое достаточно широкое применение в организации хозяйственной

\footnotetext{
${ }^{36}$ Ханнанов Р.А. Проблемы правового обеспечения внутрихозяйственного планирования и саморегулирования. // Право и политика. 2012. №7.
} 
деятельности предприятий, организаций и предпринимателей и заключении хозяйственных договоров. Такая организация хозяйствования могла бы стать одним из инструментов, препятствующих свертыванию производства и сокращению объемов продукции, с одной стороны, преодолению дефицита продукции и товаров, развитию производства, повышению уровня трудообеспеченности и оплаты труда, с другой.

Заслуживает внимания применение связанных с товарно-денежными отношениями поступков (экономических рычагов) в области капитального строительства. Речь идет, в частности, о расширении опыта строительства ряда промышленных предприятий полностью за счет кредита, предоставляемого подрядным строительным организациям в размере стоимости строящегося объекта и строительства жилья за счет средств граждан или ипотечного кредита (ст. ст. 814, 819 ГК РФ). Вызванный экономическими потребностями данный метод финансирования строительства также находит свое распространение и признание.

Все больше расширяется круг товарно-денежных связей с участием и сельскохозяйственных коммерческих организаций, что обусловлено обстоятельствами экономического порядка. Наряду с отношениями по государственным закупкам продуктов сельского хозяйства, оформляемыми договорами купли-продажи, поставки и контрактации (ст. ст. 454, 506, 525, 535 ГК РФ) и отношениями по сбыту излишков сельскохозяйственной продукции на комиссионных началах (ст. 990 ГК РФ) хозяйства могут реализовать излишки продуктов по ценам согласно договоренности с любыми организациями с полной оплатой стоимости ее при приемке. Это позволит им уйти от выполнения несвойственных для них функций торговли, сосредоточиться на производстве сельскохозяйственной продукции.

Таким образом, будучи обусловленными историческим развитием экономики и права, расширяя возможности использования товарно-денежных отношений в создании общественной собственности и упрочении хозяйственных связей между субъектами гражданского права, фактические обстоятельства (гражданские поступки) приводили и приводят к положительному социальному эффекту - конструированию правовых норм, способствующих дальнейшему развитию экономических отношений. Этим предопределялось и определяются их социально-экономическое назначение.

Значение гражданских поступков не исчерпывается только способствованием созданию объектов общественной собственности и развитию хозяйственных отношений, стимулированием правотворческой деятельности государства и т.д. Необходимость учета и оценки ряда поступков предвосхищаются еще и тем, что они служат делу обеспечения сохранности собственности, реализации имущественных интересов организаций.
К таким поступкам можно отнести совершение действий по передаче имущества (находка, клад), по выполнению работ и оказанию услуг (выполнение кредитором лежащей на должнике обязанности), по созданию, изменению или потреблению материальных благ (развивающееся на селе индивидуальное жилищное строительство, создание произведений литературы, науки, искусства), по защите материальных благ (необходимая оборона, крайняя необходимость возмещение вреда, возврат неосновательного обогащения и др.).

Так, увеличение имущества личного хозяйства на селе за счет средств, добытых преступным путем, распространенных фактов хищения, например, кормов, предназначенных для общественного скота, влечет за собой обращение взыскания на имущество этого хозяйства, чем обеспечивается охрана собственности других лиц (сельскохозяйственных) от корыстных посягательств.

В интересах охраны жилищного фонда наниматель нередко производит капитальный ремонт квартиры за счет наймодателя при уклонении последнего от ремонта.

Посредством совершения поступков стимулируется и улучшение экономических показателей организаций.

В условиях рыночной организации производства и управления им, когда работа предприятий и организаций оценивается главным образом в зависимости от заказов потребителей, от выполнения объемов реализованной продукции, от размера полученной ими прибыли и от уровня рентабельности, а не от выполнения планов закупок продукции, как это практиковалось ранее, меры, принимаемые одной из хозяйствующих единиц в интересах охраны ее имущественных прав, являются весьма эффективным средством, побуждающим другую хозяйственную организацию к улучшению качественных показателей ее работы.

Иллюстрацией сказанного могут служить, например, отказ одной организации от предоставления встречного удовлетворения до получения надлежащего исполнения от другой; оплата поставленной продукции лишь после ее качественной приемки в случае систематической отгрузки недоброкачественной продукции; отказ от договора, от принятия ненадлежащего исполнения и другие подобные поступки, порожденные товарно-денежными отношениями, отражая их свойства, служат делу защиты имущественных прав организаций ${ }^{37}$. Поэтому они достойны поддержки и в условиях рыночной организации производства. Закон и судебная практика подтверждают такой вывод ${ }^{38}$.

\footnotetext{
${ }^{37}$ Советское гражданское право. - Л.: 1971. Т. 1. С. 245-246.

${ }^{38}$ Статья 523 ГК, п.п.12, 20, 21 постановления Пленума Высшего Арбитражного Суда РФ от 22 октября 1997 г. №18 «О некоторых вопросах, связанных с применениями положений Гражданского Кодекса Российской Федерации о договоре поставки»; ст. 859 ГК РФ; п. п. 12, 13 постановления Пленума Высшего Арбитражного
} 


\section{Право и политика $1(157) \cdot 2013$}

Значительна роль гражданско-правовых поступков и в жизнедеятельности граждан. Охватывая многообразные акты человеческого поведения, поступки опосредуют передачу имущества, выполнение работ, оказание услуг между людьми (исполнение, уведомление о фактах, например, об уступке требования; отказ от исполнения и др.) или создание либо потребление благ (постройка дома и возведение надворных построек; создание произведений литературы, науки и искусства; открытия, изобретения и рационализаторские предложения; спецификация материальных объектов, а также способствование удовлетворению имущественных и личных интересов граждан (действия по охране личной собственности; выбор кредитором предмета исполнения по альтернативному обязательству; обмен информацией) и самозащита материальных и личных интересов граждан (необходимая оборона; крайняя необходимость; принуждение к действию для выполнения общественно-полезной деятельности). Указанного рода поступки направлены на обеспечение личного благосостояния граждан (удовлетворение их материальных и культурных потребностей), а в ряде случаев - также интересов государства и общества (например, создание произведений литературы, науки, искусства, открытия, ноу-хау, изобретения и др.). В этом заключается их социально-экономическое значение.

Проявляясь в многочисленных актах человеческого поведения, выражаясь в жизнедеятельности граждан и организаций, поступки оказывают определенное воздействие на социально-экономические связи: способствуют их зарождению, закреплению и упрочению, а при наличии соответствующих условий - изменению или прекращению, т.е. становятся обстоятельствами, лежащими в основе возникновения и движения общественных отношений. Как фактические обстоятельства, оказывающие известное воздействие на общественные отношения, они затрагивают интересы граждан и организаций и даже общества в целом, вызывают объективную необходимость в удовлетворении материальных и духовных потребностей. В свою очередь последние создают предпосылки для государственного определения условий возникновения и движения самих этих связей, т.е. изо дня в день повторяющихся фактических отношений производства, обмена и распределения ${ }^{39}$. Заинтересованность общества в том «...чтобы отдельный человек подчинился общим условиям производства и обмена» ${ }^{40}$, обуславливают установление охраняемых принудительной силой государства правил поведения и

Суда РФ от 19 апреля 1999 г. №5 «О некоторых вопросах рассмотрения споров, связанных с заключением, исполнением и расторжением договоров банковского счета» / Гражданский кодекс. - М.: Норма, 2004. С. 523, 524, 529.

${ }^{39}$ Маркс К. и Энгельс Ф. Соч. Т. 18. С. 272.

${ }^{40}$ Маркс К. и Энгельс Ф. Соч. Т. 18. С. 272. обстоятельств, при наличии которых эти правила подлежат применению.

Таким образом, правовое значение гражданско-правовых поступков заключается еще и в том, что в динамике социально-экономических отношений, регулируемых правом, они выполняют функцию юридических фактов ${ }^{41}$.

\section{5. Учение о поступках и совершенствование правового регулирования гражданских отношений.}

Прошедшие с момента принятия в 1994 году Гражданского кодекса Российской Федерации и законодательства, развивающего его основополагающие начала, а также практика применения содержащихся в них норм, показали, что именно последние стали руководящими устоями гражданского общества и утверждающегося цивилизованного рынка. В новых условиях существования человек и его коллективные образования стали носителями такого атрибута, как юридическое равенство субъектов, беспрепятственно осуществляющих гражданские, по своему усмотрению предпринимаемые, права, и исполняющих соответствующие этим правам обязанности.

Однако развитие современных социально-экономических отношений, их сложность и масштабность, в особенности многообразие форм социального бытия в изменившейся обстановке, форм и методов хозяйственной деятельности выдвигают на повестку дня новые задачи по инновационному обеспечению и модернизации экономики, дальнейшему совершенствованию структуры общественных связей, по улучшению правового инструментария, воздействующего на них, адекватного правового регулирования последних.

Все это требует активизации процессов становления и упрочения гражданского права, разработки научных основ его развития, проведение научных исследований и в таких важнейших направлениях, как современная интерпретация и выявление новых видов юридических фактов, создания о них стройного, отвечающего потребностям практики, одноименного учения.

Исходя из изложенного можно сформулировать следующие, могущие быть полезными и воспринятыми при совершенствовании законодательства, положения:

1. помня о том постулате, что в любом обществе примат принадлежит экономическому базису, а не надстройке, в правотворчестве следует признать в качестве

\footnotetext{
${ }^{41}$ Красавчиков О.А. Указ. соч. С. 27; Кечекьян С.Ф. Правоотношения в социалистическом обществе. - М.: 1958. С. 160-185; Толстой Ю.К. К теории правоотношения. - Л., 1959. С. 13; Алексеев С.С. Общая теория социалистического права. - Свердловск.: Указ соч. Вып. 2. С. 155-156; его же. Общая теория права. - М.: ТК Велби, Изд-во Проспект, 2008. С. 407; Мирошникова Ж.Ю. Функции юридических фактов по российскому законодательству.: Дисс. канд. юрид. наук. - Ростов на Дону, 2005 и др.
} 
доминанты формирования и развития социально-экономической деятельности именно факты - действия (IPSO FACTO). При разработке и принятии законодательных актов следует руководствоваться (отталкиваться) этим аксиоматическим положением;

2. учитывая, что указанные факты - действия (IPSO FACTO) в деятельности субъектов гражданского оборота занимают значительное место и широкое распространение, целесообразно придать им правовое значение (IPSO JURE), возвести их в ранг юридических (гражданско-правовых) поступков, вызывающих правовые последствия в виде гражданских правоотношений. Это исключит разночтение указанных обстоятельств правоприменительными органами и предотвратит административные и судебные ошибки и, как следствие этого, обеспечит возможность воздействовать на гражданские отношения в силу закона, а не только в силу самого факта;

3. принимая во внимание то, что факты-действия являются преобладающими формами возникновения и движения социальных и экономических отношений, необходимо рассматривать их во взаимной связи с научно-обоснованными установками о приоритетном обеспечении социальных свобод человека и гражданина и об устойчивом и эффективном ведении общественного производства, о государственном и правовом регулировании общественных связей;

4. имея в виду наличие объективных предпосылок для определения места фактов-действий в системе юридических фактов гражданского права (наличие собственного ареала бытия, обусловленного потребностями общественного развития, функций реализатора правовых норм, административно-судебное признание за ними качества обстоятельств, вызывающих самостоятельные или промежуточные последствия в силу самого присутствия (появления, пребывания и т.п. - IPSO FACTO), необходимо законодательно признать их элементными составляющими указанной системы, что исключит пробелы в юридической регламентации общественных связей и правовом регулировании гражданских отношений. Кроме того, такое законодательное решение будет отвечать содержанию политики государства по созданию условий для наступательного, интенсивного развития социально-экономической сферы, опирающейся на автономию личности, принцип свободы усмотрения, инициативу, установление поведения и «правил игры» своей волей и в своем интересе, дозволенную (допускаемую) правом защиту субъективных прав;

5. в интересах обеспечения верховенства гражданского законодательства ГК РФ и единства правового регулирования отношений гражданского оборота, в первую очередь имущественных отношений, основанных на фактах-действиях, и регламентируемых нормами различных отраслей права (административного, финансового, налогового, природоресурсного, экологического и др.), целесообразно отойти от принципа «специальный закон вытесняет общий» (lex specialis derogat lex generali). Здесь нормы гражданского права (законодательства) должны занимать по отношению к любым нормам других отраслей права положение первого среди равных (primus inter pares). Конституция Российской Федерации не запрещает устанавливать не противоречащую ей иерархию актов, и административная ${ }^{42}$ и судебная практика подтверждали ${ }^{43}$ и подтверждают такой вывод. В данном контексте приоритет гражданского законодательства и содержащихся в них норм вне всякого сомнения и выражает требования современного социально-экономического развития;

6. замечать и одобрять обнаружившуюся в практике административных и судебных органов тенденцию придания фактам-действиям значения юридических фактов (гражданско-правовых поступков), не ограничиваясь при этом формулировками, содержащимися в гражданском законодательстве, типа: обычаев (обычаев делового оборота), выражающихся во вне в виде правил, которые выработаны в ходе совершения поступков предпринимателями (ст.5 ГК РФ); разумности действий и добросовестности участников гражданских правоотношений, устанавливаемых исходя из существа их фактических действий (ст. 10 ГК РФ); иные заслуживающие обстоятельства (п. 2 ст. 150 ГК РФ); совершение собственником любых действий по своему усмотрению (ст. 209 ГК РФ) или в соответствии с обычно предъявляемыми требованиями (п. 1 ст. 485 ГК РФ) и т.д. и т. п., нужно идти дальше. В частности, оправданно установить правило, согласно которому любые факты-действия, если они совершены без намерения приобрести права или возложить обязанности, но направлены на достижение социально-экономических результатов, могут быть признаны правоохранительными и правоприменительными органами юридическими поступками, влекущими правовыми последствия. Для этого необходимо научно разработанное определение юридических поступков вывести на уровень законодательного правила и осуществить внутрипонятийную классификацию, отразив её, по крайней мере, в совместных разъяснениях либо постановлениях Верховного и Высшего арбитражного судов РФ. На деле это будет означать, что факты-действия объявлены областью функционирования и источником пополнения арсенала юридических фактов гражданского права, самое главное - будет способствовать развитию общеполезных форм социально - эконо-

\footnotetext{
42 Письмо Президента Российской Федерации по поводу Закона Российской Федерации «Об оценочной деятельности в Российской Федерации». / Российская газета. 1997. 14 мая.

${ }^{43}$ Судебная практика по гражданским делам (1993-1996). - М.: Юрид. бюро «Городец», 1997. С. 181-182.
} 


\section{Право и политика $1(157) \cdot 2013$}

мической деятельности, прежде всего, осуществлению творческой и производственной. Подобное решение проблемы превратит факты-действия в национальное достояние Федерации и её субъектов, способное стать идеологической и концептной основой внутренней политики государства, поможет осознать важность фактов-действий в системе политико-экономических критериев государственно-правовых и хозяйственных решений, проводимых в жизнь программных мероприятий (программ социально-экономического развития страны и регионов. Оно окажет посильное содействие активизации масс, демократизации всех форм деятельности, поможет преодолеть зависимость отечественной экономики от зарубежной, добиться экономического роста за счет обрабатывающей (производственной) части общественного хозяйства, а не за счет продажи природных ресурсов страны;

7. не умеляя особый характер фактов-действий, формирующих потребности социально-экономического порядка в виде социального обеспечения и защиты возможностей человека и гражданина, а также организации имущественных и хозяйственных связей, достижения доходности и осуществлении рентабельной деятельности и т.п., следует рассматривать указанные действия с позиции обуславливаемых ими субъективных прав, относя их к числу обстоятельств, нуждающихся в преимущественной поддержке со стороны государства и его органов. Субъективные права, порожденные признанными юридическими фактами поступками (обстоятельствами), должны интерпретироваться как общеполезные правовые образования, включающие в свой состав совокупность конкретных правовых возможностей по активизации и результативности человеческого потенциала в творчестве и производстве материальных благ, стать предметом гарантированной протекции всех участников гражданского оборота, правотворческих и правоприменительных органов всех уровней. Это позволит присовокупить названные права к числу решающего правового инструмента, способствующего результативной социально-экономической деятельности (приобретения свойств носителя социальной нагрузки, универсальности его содержания, исключительности и приоритетности, обеспеченности повышенной ответственностью за его нарушение).

Поворот государства лицом к социальным нуждам и потребностям населения и особенно переход к рыночным формам хозяйствования в экономике не отменяют государственного воздействия на общественную и производственную сферы, представляющих собой огромное множество фактов-действий физических и юридических лиц, организационно-, мотивационно- (побудительно), экономико-правовыми средствами и методами. Такое регулирование должно базироваться на поощрении оправдавших себя форм указанных актов (поступков), становящемся все более и более необходимой функцией государственного регулирования соответствующих областей влияния (мониторинг за состоянием развития населения; научно-техническим прогрессом; творчеством; обеспечением его приоритетных направлений; нравственным и преданным в последнее время забвению трудовым воспитанием; переходом от сырьевого к интенсивным факторам экономики; стимулированием активности людей; установлением и реализацией правовых гарантий и положительной ответственности ${ }^{44}$ за соблюдение и исполнение законодательства и др.), достойного концептуальной разработки и возводимого в ранг внутренней для страны политики ${ }^{45}$.

Опираясь на предыдущие выводы и положения, относящиеся к исследуемой проблеме, следует выдвинуть предложения по совершенствованию действующего гражданского законодательства об основаниях возникновения гражданских прав и обязанностей, в частности:

1. законодательно закрепить научное определение гражданско-правовых поступков;

2. изложить подпункт 8 п. (ГК РФ в следующей редакции: «вследствие иных действий граждан и юридических лиц, в том числе поступков сферы их социально-экономической и другой общеполезной деятельности»);

3. обеспечить правонаделением ${ }^{46}$ складывающуюся практику административных и судебных органов по признанию ещё не предусмотренных законом общеполезных поступков (фактов-действий) юридическими;

4. уточнить формулировку п. 2 ст. 8 ГК РФ в части, относящейся к понятию актов государственных органов и органов местного самоуправления, установив примерный перечень таких актов и включив в него планово-административные акты, а также акты (поступки), предпринятые в порядке государственного регулирования, и основанные на начинающихся зарождаться в экономике долгосрочных планах со-

\footnotetext{
${ }^{44} \mathrm{O}$ положительной ответственности см. Ханнанов Р.А., Ханнанова Т.P. Правовое обеспечение устойчивости сельскохозяйственного производства. - Уфа: АН РБ, 1997. С. 50-52.

${ }^{45}$ Доктрина продовольственной безопасности Российской Федерации, утв. Указом Президента Российской Федерации от 30 января 2010 г. (С3 РФ. 2010. №5. Ст. 502); Концепция долгосрочного социально-экономического развития Российской Федерации на период до 2020 года (СЗ РФ. 2008. №47. Ст. 5489); Государственная программа развития сельского хозяйства и регулирования рынков сельскохозяйственной продукции, сырья и продовольствия на 2013-2020 годы [Электронный ресурс] - Режим доступа: http:/ mcx.ru/documentts/document/show/16834.342.htm-07.10/2011 и др.

${ }^{46}$ Яковлев В.Ф.Указ. соч. С. 4.
} 
циально-экономического развития, (трёхлетних) перспективных финансовых планах и т.п. документов долгосрочного прогнозно-программного и директивного характера;

5. разработать концепцию о доминантном положении гражданских поступков в системе общественных отношений в стране и в структуре оснований формирования и развития социально-экономических связей, в особенности связей сферы творчества и общественного производства, как обстоятельств, предшествующих всей жизнедеятельности физических и юридических лиц, и принимаемых ими по своему усмотрению инициативных, наполненных истинно экономическим и социальным содержанием ${ }^{47}$, а потому опережающих волюнтаризм, неправовые и правовые решения; реально воплотить предлагаемую концепцию в соответствующих законах и подзаконных актах федерального и принятых на их основе законодательных актах регионального уровня, в таких, как конкретные целевые программы развития отраслей и подотраслей производства ${ }^{48}$, направлений творчества, Закона о развитии творчества и др.;

6. пересмотреть с позиции учения о юридических фактах-поступках нормы всех разделов и глав ГК РФ и отдельных гражданско-правовых актов государства, используя результаты такой работы на известных стадиях и формах систематизации гражданского законодательства.

\section{Библиография:}

1. Агарков М.М. Учение о ценных бумагах. - М.: 1927. C. 95.

2. Алексеев С.С. Общая теория права: учеб. - 2-ое изд., перераб. и доп. - М.: 2008. С. 155-156, 403.

3. Красавчиков О.А. Юридические факты в советском гражданском праве. - М.: 1958. С. 27, 154-155, 156.

4. Путин В.В. О наших экономических задачах. // Ведомости. 2012. 30 января.

5. Ханнанов Р.А., Ханнанова Т.Р. Правовое обеспечение устойчивости сельскохозяйственного производства. - Уфа: АН РБ, 1997. С. 50-52.

\section{References (transliteration):}

1. Agarkov M.M. Uchenie o tsennykh bumagakh. - M.: 1927. S. 95.

2. Alekseev S.S. Obshchaya teoriya prava: ucheb. 2-oe izd., pererab. i dop. - M.: 2008. S. 155-156, 403.

3. Krasavchikov O.A. Yuridicheskie fakty v sovetskom grazhdanskom prave. - M.: 1958. S. 27, 154-155, 156.

4. Putin V.V. O nashikh ekonomicheskikh zadachakh. // Vedomosti. 2012. 30 yanvarya.

5. Khannanov R.A., Khannanova T.R. Pravovoe obespechenie ustoychivosti sel'skokhozyaystvennogo proizvodstva. - Ufa: AN RB, 1997. S. 50-52.

47 Ханнанов Р.А. Проблемы правового обеспечения внутрихозяйственного планирования и саморегулирования. // Право и политика. 2012. №7.

${ }^{48}$ Ханнанов Р.А. Производственная деятельность-основа правовой организации современной экономики / Вестник Башкирского государственного аграрного университета. 2007. №9. С. 33-39; его же: Новая парадигма правового обеспечения устойчивости растениеводства. // Право и политика. 2012. №1. С. 109-1302; его же: Стратегия развития животноводства России: организационноэкономические и правовые проблемы. // Право и политика. 2012. №2. C. 339-363. 